\title{
Grazing Behavior and Itineraries of Kacang Goat with Different Coat Color under Semi Intensive Management
}

\author{
Slamet Heri Kiswanto1)*, Muhammad Baihaqi ${ }^{1)}$ and Iwan Prihantoro ${ }^{2)}$ \\ 1)Department of Animal Production and Technology, 2)Department of Feed Nutrition and Technology, Faculty of Animal \\ Science, Bogor Agricultural University, Jl. Agatis, Kampus IPB Darmaga, Bogor 16680, Indonesia \\ Corresponding E-mail: iptpsheri@gmail.com
}

\begin{abstract}
The objective of this research was to analyze the effect of coat color on behavior and itineraries of kacang goat during grazing time. This research used 9 females and 3 males kacang goat. Behavior observed by one zero sampling method and analyzed using t-Test at level 5\%. The result indicated that ingestion and browsing of brown goat $(30.91 \pm 2.87 \% ; 8.75 \pm 3.10 \%)$ higher than black goat $(28.57 \pm 2.69 \% ; 6.07 \pm 4.78 \%)$, while black goat showed more locomotion $(33.26 \pm 4.50 \%)$ than brown goat $(29.70 \pm 4.63 \%)$. Grazing, panting, and resting behaviors, and distance traveled of black goat $(22.56 \pm 2.63 \% ; 4.48 \pm 4.02 \% ; 2.34 \pm 2.97 \% ; 483.48 \pm 133.16$ $\mathrm{m}$ ) were not different with brown goat (22.16 $\pm 2.90 \%$; $4.59 \pm 3.71 \% ; 2.64 \pm 1.52 \% ; 392.29 \pm 81.19 \mathrm{~m})$. Result also indicated that goat showed more grazing than browsing with high preference in young grass than old grass, legume, and weed.
\end{abstract}

Key words: behavior, color, distance traveled, kacang goat

\begin{abstract}
Abstrak. Penelitian ini dilakukan untuk menganalisis pengaruh perbedaan warna kulit terhadap tingkah laku harian dan jarak jelajah kambing kacang selama penggembalaan. Penelitian enggunakan kambing kacang terdiri atas 9 ekor betina dan 3 ekor jantan. Tingkah laku diamati dengan teknik one zero sampling dan dianalisis dengan uji $\mathrm{T}$ pada taraf $5 \%$. Hasil penelitian menunjukkan tingkah laku ingestion dan browsing kambing coklat $(30.91 \pm 2.87 \%$; $8.75 \pm 3.10 \%)$ lebih tinggi dibandingkan dengan kambing hitam $(28.57 \pm 2.69 \%$; $6.07 \pm 4.78 \%)$, sebaliknya lokomosi kambing hitam (33.26 $\pm 4.50 \%)$ lebih tinggi dibandingkan dengan kambing coklat (29.70 $\pm 4.63 \%)$. Tingkah laku grazing, panting, istirahat, dan jarak jelajah kambing hitam $(22.56 \pm 2.63 \%$; $4.48 \pm 4.02 \% ; 2.34 \pm 2.97 \% ; 483.48 \pm 133.16 \mathrm{~m})$ dan kambing coklat $(22.16 \pm 2.90 \% ; 4.59 \pm 3.71 \% ; 2.64 \pm 1.52 \%$; $392.29 \pm 81.19 \mathrm{~m}$ ) tidak berbeda nyata. Tingkah laku grazing oleh kambing kacang lebih banyak dilakukan dibandingkan browsing dengan preferensi terhadap rumput muda lebih tinggi dibandingkan dengan rumput tua, leguminosa, dan gulma.
\end{abstract}

Kata kunci: jarak jelajah, kambing kacang, tingkah laku, warna

\section{Introduction}

Kacang goat is Indonesian native goat for meat producer. Data from Directorate General of Farming and Veterinary Directorate General of Farming and Veterinary (2012) showed that Kacang goat's population was 7.5 million. People used semi intensive management system to manage Kacang goat. Animut et al. (2005) reported that semi intensive system affected goat behavior and energy expenditure.

Kacang goat could be classified into two based on coat colors, brown and black. This difference affected the feed intake (Wallace and Abadi, 2013) and the absorption of solar radiation (McManus et al., 2011) during grazing time. Goetsch et al. (2009) reported that the observation of goat behavior and grazing itineraries could be used as reference for pasture management, feeding time and also feed preference (Kenward, 2001). The objective of this research was to analyze the effect of different coat color on grazing behavior and itineraries of Kacang goat managed under semi intensive management.

\section{Materials and Method}

\section{Preparation of experimental animal}

Twelve Kacang goats with initial average body weight of $13.83 \pm 3.08 \mathrm{~kg}$ and $1-1.5$ years 
old with different coat color types (black and brown) were used in this experiment. Goats were managed under semi intensive system in individual slatted floor pens at Field Laboratory of Small Ruminant Block B, Faculty of Animal Science, Bogor Agricultural University, Bogor. The mean ambient temperature ranges from $29^{\circ} \mathrm{C}$ to $31^{\circ} \mathrm{C}$ during January until March 2014 with average humidity about $73 \%$. Goats were fed with concentrates and forages in grazing area. Grazing behavior and itineraries of Kacang goats was observed when they were on grazing land. The treatment was coat color (black and brown) with six replications.

\section{Observation of behavior}

During observations, the following goat activities were recorded: browsing, grazing and locomotion activities. Browsing activity included bi-pedal stance (recorded separately) and represented the browsing of all woody species. Tree or bush species browsed at the time of recording were visually identified and separately recorded. Grazing activity represented the grazing of grasses without the identification or recording of species. Locomotion activities included separate recordings of walking, standing, and lying. Each goat was observed for 15 minutes each hour from 11 to 16.00 hours. The observation of behavior used one zero sampling technic (Martin and Bateson, 1993).

Behavior $=\frac{X}{Y} \times 100 \%$

Where, $X$ represented frequency of one behavior per individual and $Y$ represented total frequency of behavior observed per individual during 6 hours.

\section{Observation of grazing itineraries}

Goat movement was observed using global positioning system (GPS) Garmin Oregon 550 and digital camera digital Finepix XP150, then interpreted by Geotage software. Distance traveled during grazing was measured using Precimeter three times.

\section{Data analysis}

During 15 minute observation, the time spent on different activities (grazing, browsing, locomotion, resting, panting) by a goat was recorded in minutes and later converted into percentage. Data analysis was conducted using $\mathrm{t}$-Test. The significance of a factor on a given feeding behavior was tested at $P=0.05$. The following statistical model was used on each activity (Walpole, 1995).

$\mathrm{t}=\frac{(\overline{\mathrm{y}} \mathrm{a}-\overline{\mathrm{y}} \mathrm{b})-(\mu \mathrm{a}-\mu \mathrm{b})}{s b \sqrt{\left(\frac{1}{\mathrm{na}}+\frac{1}{\mathrm{nb}}\right)}}$

where $\bar{y}_{a}$ is mean of sample $a, \bar{y}_{b}$ is mean of sample $b, \mu_{a}$ is mean of population $a, \mu_{b}$ is mean of population $b, s b$ is standard deviation of sample $b, n_{a}$ is number of sample $a$, and $n_{b}$ is number of sample $b$.

\section{Results and Discussion}

\section{Situation of vegetation}

Types of vegetation in pasture land are shown at Table 1 . Vegetation in pasture consists of forage such as Brachiaria humidicola (Rendle) Schweickand Paspalum cartilageneum J. Presl, legume such as Gliricidia sepium (Jacq.) Kunth ex Walp, and weed such as Melastoma affine D. Don, Cyperus kyllingia Endl., and Chromolaena odorata (L.) R.M. King \& H. Rob. The vegetation spread out at any location in pastureland. Carrying capacity of young grass in this research was $0.94 \pm 0.42 \mathrm{AU}$ (animal unit) per hectare equal with six goats. Accordingly, 1 animal required $1.21 \mathrm{Ha}$ grazing area for a year. High production in young grass was affected by high rainfall intensity during wet season. In line with Goetsch et al. (2009), that the availability of type and vegetation level for goat were affected by season support this. The research found that both old and young Brachiaria humidicola grass expanded at some location in pastureland. Maps of vegetation distribution is shown in Figure 1 . The distribution of vegetation is classified into three area, young grass area, old grass area, and weed area 
measuring $1033 \mathrm{~m}^{2}(7.77 \%), 4038 \mathrm{~m}^{2}$ (30.36\%) and $791 \mathrm{~m}^{2}$ (5.95\%), respectively, and the combination of weed, legume, and tree was $7473 \mathrm{~m}^{2}$ (55.92\%).

Behavior of grazing, browsing, locomotion, resting, and panting

The grazing activity such as ingestion, grazing, browsing, locomotion, resting, and panting were shown in Table 2, Table 3, and Figure 1. Feeding behavior (ingestion) of black Kacang goat during six hours was significantly higher $(\mathrm{P}<0.05)$ than brown Kacang goat. It was due to the interaction between coat color and solar radiation during grazing time. Similar to McManus et al. (2011) and Wallace and Abadi (2013) that brown color absorbed less solar radiation than black. Dark coated animals were predisposed to higher heat load so feed intake per unit body weight, the digestibility and nutrient absorption from the intestine decreased with increase in heat stress caused by solar radiation. The expose of environmental temperature stimulated the peripheral thermal receptor of animal to transmit suppressive nerve impulses to the appetite center in the hypothalamus, decreasing feed intake. Table 5 showed that the feeding activity of Kacang goat during the 11.00-12.00 hour and 12.00-13.00 hour increased and decreased during 13.0016.00 hours. Setianah et al. (2004) reported that goat spent more feeding time in morning and evening.

Grazing behavior of black Kacang goat was not different $(P>0.05)$ from that of brown, however in browsing activity both black and brown Kacang goat showed significant difference $(P<0.05)$ in that significantly higher $(P<0.05)$ in brown than black. Wallace and Abadi (2013) reported that brown sheep showed more grazing activity than black sheep, indicating lower browsing frequency grazing, similar to Lebopa et al. (2011) that reported $67 \%$ grazing compared to $33 \%$ browsing. It was $\mathrm{n}$ contrast with Berhane and Eik (2006), Aharon et al. (2007) and Yayneshet et al. (2008), that goat preferred browsing to grazing. The number and distribution of rainfall (Lu, 1987) affected this difference. Ouédraogo et al. (2006) reported that during dry season, goat spent more time to browse than graze, opposite to wet season.

Locomotion activity of black Kacang goat increased at 13.00-16.00 hours and decreased at 11.00-13.00 hours. At 13.00-16.00 hours black Kacang goat increased in locomotion because at this time the solar absorption was higher than brown (McManus et al.,2011). The higher solar absorption made black goat walk and look for shade to lower the heat. However, brown goat received lower solar radiation than black, so goat did not want to walk or look for shade, thus feed intake increased (Wallace and Abadi, 2013). Solar absorption in goat coat could be associated with coat surface temperature when exposed to solar radiation.

According to Table 2, resting activity between black and brown Kacang goat was not different $(P>0.05)$. However, this activity increased at 13.00-14.00 hours and 14.00-15.00 hours affected by the ambient temperature increment. Setianah et al. (2004) reported that resting activity increment optimally occurred at 11.00-13.00 and 15.00-16.00, exposed by high ambient temperature at $27{ }^{\circ} \mathrm{C}-34{ }^{\circ} \mathrm{C}$, so goat preferred resting to grazing. Beside resting activity, goat also showed panting especially during 12.00-13.00 hours where goat received more solar radiation. Redbo et al. (1996) reported that grazed goat easy to be exposed to heat from solar radiation, so they did more resting, panting, and seeking shelter to reduce radiation received by their body. Goat rested to decrease the heat loss in some condition (Redbo et al., 1996). Maloney et al. (2005) also reported that besides resting and panting, goat will change their position to solar radiation to reduce the exposure of solar radiation. 

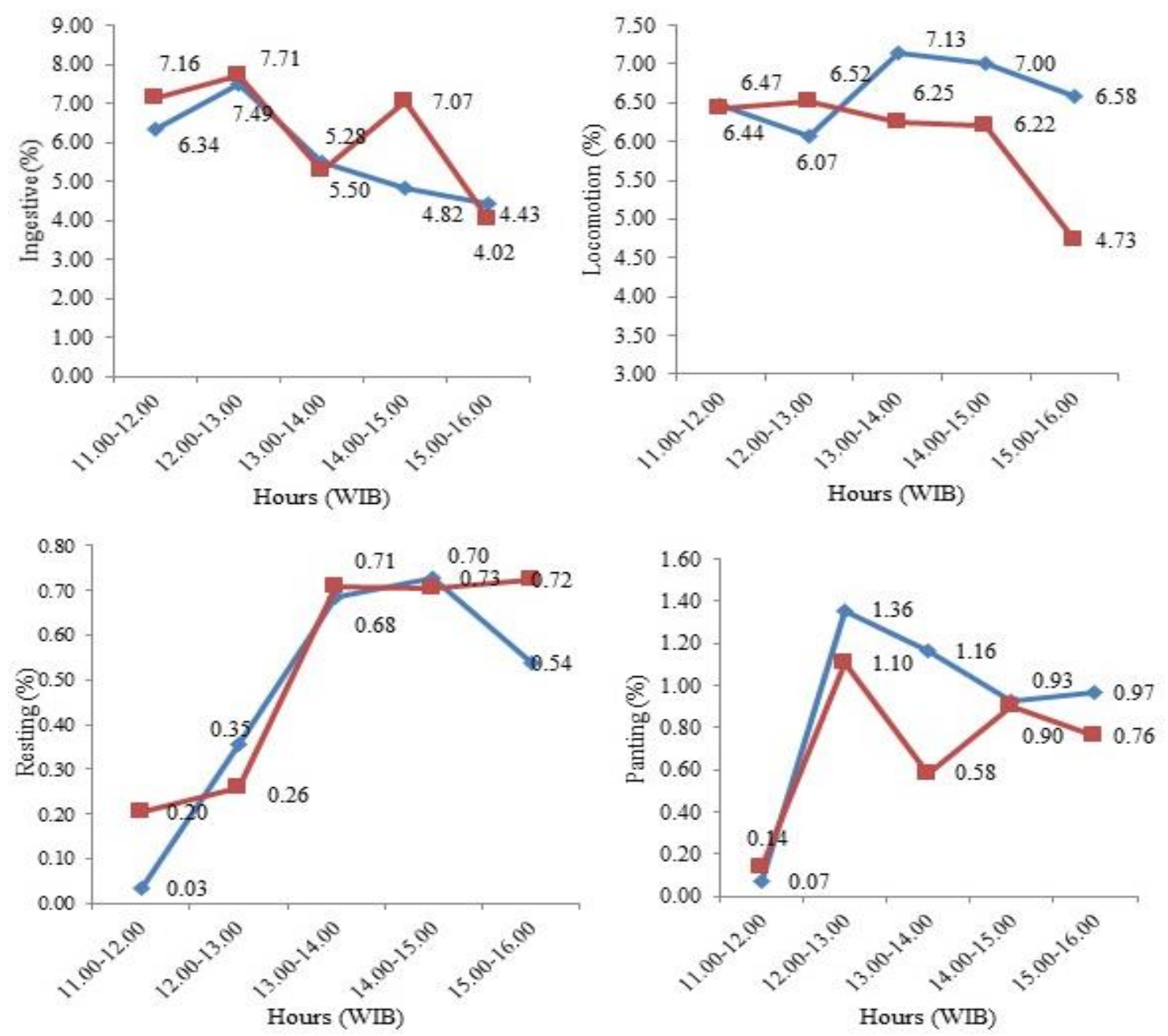

Figure 1. Frequency of ingestion, locomotion, resting, and panting activity of kacang goat during 11.00-16.00 hours observation in pasture land. The blue line was for Black Kacang Goat, while red line was for Brown Kacang Goat

Table 1. Types of vegetation in pasture land

\begin{tabular}{lcc}
\hline \multicolumn{1}{c}{ Latin name } & Local name & Type \\
\hline Brachiaria humidicola (Rendle) Schweick & BH's grass & Grass \\
Paspalum cartilageneum J. Presl & - & Grass \\
Gliricidia sepium (Jacq.) Kunth ex Walp & Gamal & Legume \\
Melastoma affine D. Don & Harendong & Weed \\
Cyperus kyllingia Endl. & Teki badot & Weed \\
Chromolaena odorata (L.) R.M. King \& H. Rob & Ki rinyuh & Weed \\
\hline
\end{tabular}

Table 2. Frequency of daily activity of kacang goat during experiment

\begin{tabular}{lcc}
\hline \multirow{2}{*}{ Behavior or activity } & \multicolumn{2}{c}{ Frequency (\%) } \\
\cline { 2 - 3 } Ingestion & $29.33 \pm 1.29^{\mathrm{b}}$ & $31.61 \pm 1.57^{\mathrm{a}}$ \\
- Grazing & $23.17 \pm 1.10$ & $23.50 \pm 1.29$ \\
- Browsing & $6.22 \pm 0.39^{\mathrm{b}}$ & $8.11 \pm 0.61^{\mathrm{a}}$ \\
Locomotion & $34.29 \pm 0.46^{\mathrm{a}}$ & $30.60 \pm 0.75^{\mathrm{b}}$ \\
Resting & $4.56 \pm 0.51$ & $3.53 \pm 0.37$ \\
Panting & $2.43 \pm 0.29$ & $2.65 \pm 0.27$ \\
\hline
\end{tabular}

Mean value bearing different superscript at the same row indicates significantly different $(P<0.05)$ 
Table 3. Grazing and browsing activity of kacang goat during experiment

\begin{tabular}{ccccc}
\hline \multirow{2}{*}{ Hours (WIB) } & \multicolumn{2}{c}{ Grazing(\%) } & \multicolumn{2}{c}{ Browsing(\%) } \\
\cline { 2 - 5 } & Black & Brown & Black & Brown \\
\hline $11.00-12.00$ & $5.70 \pm 1.93$ & $6.09 \pm 1.31$ & $0.81 \pm 0.76$ & $1.17 \pm 0.60$ \\
$12.00-13.00$ & $5.92 \pm 2.91$ & $5.85 \pm 1.19$ & $1.81 \pm 1.08$ & $1.97 \pm 1.31$ \\
$13.00-14.00$ & $4.21 \pm 1.53$ & $3.81 \pm 1.70$ & $1.42 \pm 1.59$ & $1.52 \pm 1.38$ \\
$14.00-15.00$ & $3.77 \pm 1.47$ & $4.66 \pm 0.78$ & $1.20 \pm 1.29$ & $2.47 \pm 1.73$ \\
$15.00-16.00$ & $3.57 \pm 1.43$ & $3.08 \pm 1.91$ & $0.98 \pm 0.84$ & $0.98 \pm 1.03$ \\
\hline Total & $23.17 \pm 1.10$ & $23.50 \pm 1.29$ & $6.07 \pm 0.39^{\mathrm{b}}$ & $8.11 \pm 0.61^{\mathrm{a}}$ \\
\hline
\end{tabular}

Mean value bearing different superscript at the same row indicates significantly different $(\mathrm{P}<0.05)$

\section{Grazing pattern and distance traveled of goat}

Grazing pattern of Kacang goat was shown in Figure 2. Grazing pattern of Kacang goat was centered in area dominated by young Brachiaria humidicola's grass. The high preference of young grass than old grass was affected by rainfall intensity. The young plant contained a low crude fiber but high crude protein and moisture (Ella, 2002). Goat preference towards old grass was lower than young grass because of nutritive value. The content of crude fiber and lignin was high (Moore and Jung, 2001; Ribeiro et al.,2012) so the palatability was lower than before. The map of grazing pattern is shown in Figure 2 .

No difference found ( $P>0.05)$ between distance traveled of black Kacang goat $(483.48 \pm 133.16 \mathrm{~m})$ and brown $(392.29 \pm 81.19$ $\mathrm{m})$. The result was higher than Pariadi et al. (2001) but lower than Foroughbakhch et al. (2013). Pariadi et al. (2001) reported that native goat managed under semi intensive system in Central Kalimantan had average 205 $\mathrm{m}$ distance traveled, while Foroughbakhch et al. (2013) also reported $2200 \mathrm{~m}$ in semiarid area.
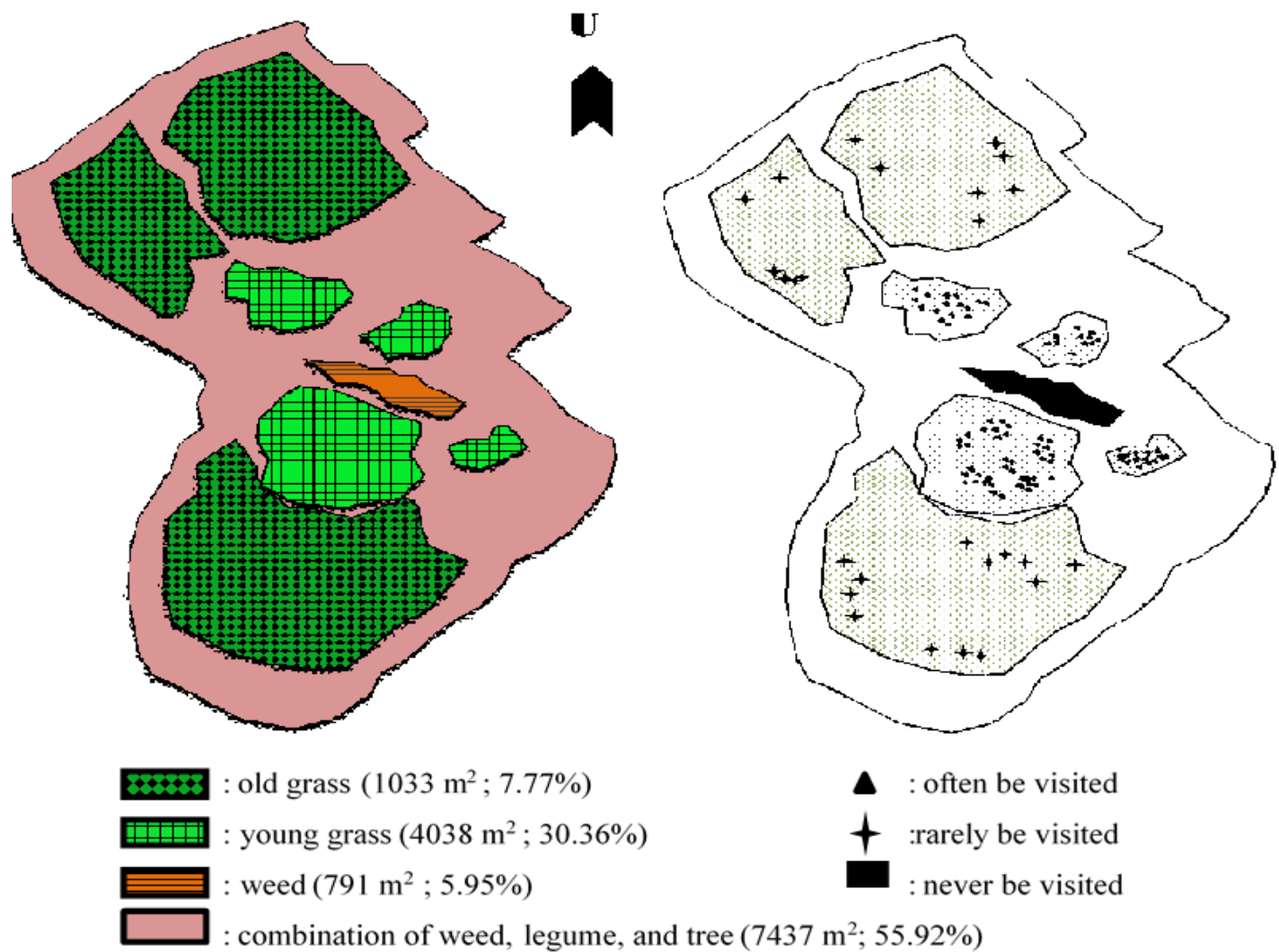

: old grass $\left(1033 \mathrm{~m}^{2} ; 7.77 \%\right)$

: young grass $\left(4038 \mathrm{~m}^{2} ; 30.36 \%\right)$

: weed $\left(791 \mathrm{~m}^{2} ; 5.95 \%\right)$

$\Delta$ : often be visited

t rarely be visited

: never be visited

: combination of weed, legume, and tree $\left(7437 \mathrm{~m}^{2} ; 55.92 \%\right)$

Figure 2. Grazing pattern of kacang goat during grazing time in pasture land 
Result indicated that the forage composition in pastureland was high and diverse. This condition caused the goat grazing and browsing more than walking. It was in line with Pariadi et al. (2002) that the rich pasture land may consisted of many types of vegetation as source of feed, so the distance traveled became lower.

\section{Conclusions}

Grazing activity of Kacang goat was dominated with locomotion, followed by ingestion, grazing, and browsing during grazing time. Ingestion and browsing in black Kacang goat was higher than brown. However, the locomotion activity of brown Kacang goat was higher than black. The preference of goat to young was grass higher than old grass, legume, and weed.

\section{References}

Aharon H, Z Henkin, ED Ungar, D Kababya, H Baram and A Perevolotsky. 2007. Foraging behaviour of the newly introduced Boer goat breed in a Mediterranean woodland: A research observation. Small Rumin. Res. 69: 144-153.

Animut G, AL Goetsch, GE Aiken, R Puchala, G Detweiler, CR Krehbiel, RC Merkel, T Sahlu and LJ Dawsin. 2005. Grazing behavior and energy expenditure by sheep and goats co-grazing grass forb pastures at three stocking rates. Small Rumin Res. 59: 191-201.

Berhane G and LO Eik. 2006. Effect of vetch (Vicia sativa) hay supplementation to Begait and Abergelle goats in Northern Ethiopia: III Forage selection and behaviour. Small Rumin. Res. 64: 241-246.

Direktotat Jendral Peternakan dan Kesehatan Ternak. 2012. Statistik Peternakan dan Kesehatan Hewan 2012. Direktorat Jenderal Peternakan dan Kesehatan HewanKementerian Pertanian RI, Jakarta.

Ella A. 2002. Produktivitas dan nilai nutrisi beberapa renis rumput dan leguminosa pakan yang ditanam pada lahan kering iklim basah. Balai Pengkajian Teknologi Pertanian, Makasar.

Goetsch Al, TA Gipson, AR Askar and R Puchala. 2009. Feeding behavior of goat. J. Anim. Sci. 88: 361-373.

Lebopa CK, EA Boomker, M Chimonyo and SD Mulugeta. 2011. Factor affecting the feeding behavior of free ranging Tswana and Boer goats in the False Thornveld of the Eastern Cape, South Africa. Life Sci. J. 8: 70-80.

Martin P and P Bateson. 2007. Measuring Behaviour. Third Edition. Cambridge University Press, London.

Moore KJ and HJG Jung. 2001. Lignin and fiber digestion J. Range Manage. 54: 420-430

Kenward RE. 2001. A Manual for Wildlife Radio Tagging. Academic Pr, London.

Lu CD. 1987. Implication of forage particle length on milk production in dairy goats. J. Dairy Sci. 70: 1411-1416.

Maloney SK, G Moss and D Mitchell. 2005. Orientation to solar radiation in Black Wildebeest (Connochaetes Gnou). J. Comp. Physiol. 191(11): 1065-1077.

McManus C, H Louvandini, R Gugel, LCB Sasaki, Bianchini, FEM Bernal, SR Paiva, and TP Paim. 2011. Skin and coat traits in sheep in Brazil and their relation with heat tolerance. Trop. Anim. Health Prod. 43: 121-126.

Ouédraogo S, CY Zoungrana-Kabore and I Ledin. 2006. Behaviour of goats, sheep and cattle on natural pasture in the sub-humid zone of West Africa. Livest. Sci. J. 105: 244-252.

Pariadi A. 2002. Grazing behavior of local adult goat grazed in swamp area of secondary forest of Palangkaraya, Central Kalimantan. Disertation. Bogor Agriculture University, Bogor.

Foroughbakhch R, JL Hernández-Piñero, A CarrilloParra and A Rocha-Estrada. 2013. Composition and animal preference for plants used for goat feeding in semiarid Northeastern Mexico. J. Anim. Plant Sci. 23(4): 1034-1040.

Redbo I, I Mossberg, A Ehrlemark and N Oredsson. 1996. Keeping growing cattle outside during winter: behavior, production, and climatic demand. J. Anim. Sci. 62: 35-41.

Ribeiro AM, ME Olieveira, PC Silva, MOA Rufino, MM Rodrigues and MS Santos. 2012. Canopy characteristics, animal behavior and forage intake by goats grazing on Tanzania-grass pasture with different heights. Acta Sci. Anim. Sci. 34(4): 371-378.

Setianah R, S Jayadi and R Herman. 2004. Grazing Behavior of local Crosses goat at the Grazing Peatlands: A Case Study in Kalampangan, Palangkaraya, Central Kalimantan. Med. Pet. 27(3): 111-122.

Solanki GS. 2000. Grazing behaviour and foraging strategy of goats in semi-arid region in India. J. Trop. Eco. 41(2): 155-159.

Wallace A and I Abadi. 2013. The Effect of coat colour on water intake and feed utilization of intensively reared West African Dwarf Sheep in 
Slamet Heri Kiswanto et al./Animal Production. 17(2):107-113, May 2015

Accredited by DGHE No. 81/DIKTI/Kep./2011. ISSN 1411-2027

the Humid Tropics. European J. Agric. Sci. 10: 2668-3245.

Walpole RE. 1995. Pengantar Statistika. Gramedia Pustaka, Jakarta.
Yayneshet T, LO Eik and SR Moe. 2008. Influence of fallow age and season on the foraging behaviour and diet selection pattern of goats (Capra hircus L.). Small Rumin. Res. 77: 25-37. 